\title{
Códigos de linguagem no discurso sobre o cinema
}

Rosemari Fagas Viégas e Paulo Sérgio Marchell Universidade de São Marcos 


\section{Resumo}

Este trabalho consiste em um estudo sobre os códigos da linguagem cinematográfica a partir de seus significados estético, psicológico e sociológico. Adotam-se como pontos de vista teóricos a divisão tricotômica dos signos proposta por Charles S. Peirce, a revisão crítica da Teoria da Imagem, a descrição de Walter Benjamin sobre a natureza política inerente aos processos técnicos de produção filmica e a hipótese de que as respostas às questões apontadas pela análise do cinema, realizada por Christian Metz, dependem da solução de problemas lógicos da construção de classes de significação dentro da semiótica. O método utilizado é tanto o bibliográfico quanto aquele baseado em análise de filmografia selecionada. O trabalho procura explicitar a nova classe de signos e de representações que a linguagem digital do cinema deverá produzir no futuro próximo.

\section{Palavras-chave}

comunicação, linguagem, semiótica, cinema, estética, tecnologia

\section{Abstract}

This paper consists of the study of movies language codes from their esthetic, psychological and sociological significances. The trichotomic sign division, suggested by Charles S. Peirce, has been considered as theoretical points of view, as well as the Image Theory preview, Walter Benjamin's description on political nature which is inherent to the movies production technical procedures, and also the hypothesis that the answers to those questions which have been pointed out in a movies analysis made by Christian Metz depend upon the solution of some logical problems concerning the making of significance classes in Semiotics. The bibliographical method and also the one based on selected movie analysis were used in the study. Thus, in aims to present a new class of signs and the representations which might be produced in digital movies language in a near future.

\section{Key words}

communication, language, semiotics, movies production, esthetics, technology 
is :

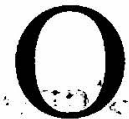

cinema é a arte das ímagens em moviménto, ưma séquência fotográfica que, ao ser projetada e reproduzir a realidade registrada pêla câméra, ĉ̀nsegue suscitar, ina palavras de Benjamin (1980, p. 23), "a experiência do inconsciente visual, assim como a psicanálise nos abre a experiência do inconsciente coletivo". No início do cinema, apenas a pura ilusão do movimento na tela já.provocava reações intensas.nos telespectadores, ao verem, por exemplo, as folhas das árvores palpitarem sob,o vento ou o trem avançar para eles vindo do horizonte. Com o acréscimo do enredo, surge o filme como dramaturgia ou comédia, aproximando-se do teatro. $\mathrm{O}$ som aparece como um elemento importante da produçã̃o cinematográfica, permitindo reconstituir o ambiente completo dos seres e das coisas presentes na vida real. O campo visual associado à audição engloba a totalidade do espaço real e permite ao éspectador deixar-se envolver muito mais facilmente pela mágica ilusão do movimento. A técnica do desenho animádo aproximou o cinema das artes gráficas e o computador proporcionou a difusão dos efeitos especiais que sustentam bilheterias milionárias. Atualmente, discutemse qual é a estética proposta pelas novas tecnologias e quais são as possibilidades de a produção filmica superar limites ainda não testados.

$O$ interesse crescente pelo estudo do cinéma, sob o ponto de vista da semiótica; estabelece ćaminhos para a construção de um sistema lingüístico de significação capaz de incluir ao mesmo tempo a crítica e a estética. Nesses caminhos, os elementos da iarte cinematográfica se dissolvem no bojo da ciência geral dos signos, exprimindo-se segundo o comportamento coletivo e 'a convenção social. A tônica do presente trabalho é.enfocar criticamente ós fundamentos da análise semiológica e do campo da compreensão estética presentes nas teorias do:cinema, mostrando de que forma 
essas teorias são influenciadas pelos alcances técnicos de sua época. O trabalho faz, inicialmente, uma revisão de como a arte cinematográfica é categorizada a partir da ciência geral dos signos peirceana, estabelecendo condições para a apresentação da crítica à técnica do filme como imagem em movimento, vista com câmera parada. Busca-se adentrar, dessa forma, no campo da semiótica para compreender quais representações estão em jogo no processo de vivência do signo cinematográfico pelo telespectador.

\section{A categoria indicial primária do signo cinematográfico}

Em primeiro lugar, será preciso caracterizar o cinema em termos da sua distinção dos aspectos convencionais observados na imagem instantânea, a fotografia, da que se serve para produzir movimentos. A fotografia, em geral, representa os objetos exatamente como eles são observados, estabelecendo uma semelhança que se deve ao fato de ser produzida em circunstâncias tais que é fisicamente forçada a corresponder ponto por ponto à natureza e, sob esse aspecto, então, pertencem à segunda classe dos signos, aqueles que o são por conexão fisica. (Peirce, 1995, p. 65)

Um signo é tudo o que não é certa coisa, mas representa essa coisa para um interpretante, fazendo com que esse último estabeleça uma determinada relação com a coisa interpretada. Essa relação pode ser genuína ou degenerada, dependendo de como a coisa ou objeto é representado pelo interpretante. Quando a relação é degenerada, é porque o signo estabeleceu para o interpretante uma representação genérica sobre qualidades pertencentes ao todo de um conjunto de objetos individuais que conservam em comum aquelas qualidades, mas que são diferentes entre si. A relação de ordem estabelecida quando se diz, por exemplo, "A é maior do que B", é degenerada, pois há um conjunto de objetos que podem substituir $\mathrm{A}$ e $\mathrm{B}$, satisfazendo a relação. Uma relação genuína é a que permite ao interpretante estabelecer entre o signo representante e o objeto representado uma total independência em termos das suas qualidades 
individuais. Assim, quando se diz, "5 é maior do que: 3 ", a relação é genuína, pois ela faz parte da natureza específica dos objetos representados, que são os números 3 e 5 . Dessa forma, todo signo apresenta um grau de degenerescência que varia do mais degenerado ao mais genuíno.

Um signo que representa uma coisa para o interpretante dentro de umalto grau de degenerescência é dito um originaliano, ou icone, assim explicado por Peirce: [...] é um signo cuja virtude significante se deve apenas à sua qualidade. Já o signo degenerado no menor grau é denominado obsistente ou índice, ou seja, [...] é um signo cuja significação de seu objeto se deve ao fato de ter. ele uma relação genuina com aquele objeto, sem levar em conta $o$ interpretante. (p. 28)

O grau de degenerescência de um signo diz respeito somente à relação que o mesmo estabelece com a coisa representada para o interpretante. Se, independentemente do interpretante, o signo continua em si mesmo a representar aquela coisa, então ele é um índice. Mas se o signo necessita da participação de um interpretante para ter sentido, então ele é um ícone. Quando o caráter de significação não puder existir sem a participação total do interpretante, ou seja, quando o signo somente puder ser compreendido com a ajuda de alguém que impreterivelmente deva estar presente para estabelecer o significado, então ele é um símbolo. Um símbolo é um signo cuja virtude significante se deve a um caráter que só pode ser compreendido com a ajuda de seu Interpretante. A emissão de um discurso é exemplo disto: as palavras representam os objetos e significam suas qualidades na mente do ouvinte por meio dos signos correspondentes. (p. 28-9).

De fato, não há maior grau de degenerescência do que entre uma palavra e a coisa que ela representa. A palavra "boi", por exemplo, em si mesma; representa apenas o som que designa um animal classificado em termos de suas qualidades próprias. Nenhuma relação há, em princípio, ;entre a palavra em si mesma e a coisa que ela representa. É preciso que um interpretante esteja presente para aferir o significado da palavra por meio de uma lei, normalmente dada por uma asssociação de idéias que age no sentido de permitir que o símbolo 
seja interpretado como aludindo àquele objeto. Um símbolo não indica uma coisa particular, mas uma espécie de coisa. Podemos escrever a palavra 'estrela', porém isso não faz, de quem a escreveu, o criador da palavra, assim como, se apagarmos a palavia, não a destruimos (p. 73). Dessa forma, a palavra descreve ö estado mental dos que a usam e ela existe mesmo no estado de sonio das pessoas.

$\mathrm{Na}$ lógica peirceana, o cinema está situado dentro das categorias indiciais, sendo fisicamente constituídö pela imagem fotográfica e formando um par orgânico com a palavia simbólica. A montagem cinematográfica somente se aproxima do objeto que representa por meio de sensações criadas por analogia na mente do interpretante. Além das palavras falada e escrita; o telespectador dispõe da fotografia para o registro e processamento da mensagem em sua mente. Entre os símbolos representados pela palavra e a imagem fotográfica projetada na tela, o telespectador intercala seus referenciais culturais para realizar a interpretação. $O$ cinema forma ícones que possuem graus de degenerescência muito pequenos, aproximando-se, assim, dos signios indiciais.

Dessa forma, o cinema nunca poderá ter uma verdadeira linguagem, pelo menos nos termos de como a palavra simbólica é representada pela mente. Nas palavras de Christian Metz, a linguagem cinematográfica é o conjunto dos códigos $e$ subcódigos cinematográficos, na medida em que se deseja falar dela como de um amplo objeto único (Metz, 1980, p. 156). Para Roland Barthes (1971), de quem Christian Metz foi discipulo, o ícone fotográfico só pode representar objetós em seu estado puro, e, desse modo, a possibilidade de intervenção humana é mínima, pois na relação do interpretante com o cinema, não há códigos pré-estabelecidos, como ocorre na linguagem verbal. À fala do cinema também não podem ser intercalados' signos de interpretação, pois refere-se à fotografia, que é uma mensagem sem código. Barthes, como peirceano que foi, coloca a imagem e a palavra como um par orgânico indicial de complementação, na qual a fala justifica a produção do movimento.

Ao colocar a semiótica como um ramo da lingüística, Barthes (1985) se apóia na hipótese de que a experiência cinematográfica 
sugere uma grande complexidade:de significações obtidas através de imagens. Mas a fotografia é uma linguagem sem códigos, pois esses se manifestam para o interprètante apenas por meio dos símbolos da fala, que não estão presentes nos níveis indicais, mas entram ná composição icônica do cinema. O sentido mais amplo da mensagem barthesiana é de que não há uma lógica no cinema. Um filme pođè levar o telespectador para quialquer lugar, desde o mais remoto passado ao futuro distante; de forma que estè não sinta nenhuma motivação para interpretar súa viagem, pois não dispõe de códigos pré-existentes, a não ser os do presente, e ëstes pódem ser transformados pela fala. Somente esta última póde ser real para-o interpretante. $O$ cinema é praticamente ilusão de ótica; portanto, irreal e apenas diversão.

O interpretante dà linguagem oral possui um conjunto de códigos referenciais pré-estabelecidos pela cultura que não o deixàm desviarse pela ilusão do real presente e este é o motivo pelo qual o cinema não pode ter ou constituir umá linguagem propriamente dita, pois ele desloca o telespectador pela conjugação da imagem em mövimento com a fala. Para o interpretante simbólico da linguagem fálada, somente a imagem real pode referir o presente por meio da existênicia física. A mente não é capaz de reconstituir fisicamente o passado, a não ser uma reconstituição por evocações e lembranças não físicas, entretanto, o cinema interpõe ao interpretante as fotografias que indicam, no presente, o passado e o futuro por meio de imagens que ilustram o enredo falado do roteiro do filme. Desta forma, quebra-se o sistema de referência do código falado e as imagens projetam espaços distantes que desviam a convergência simbólica dos rumos pré-estabelecidos existentes na mente do interpretante No cinema, toda interpretação é válida, ao mesmo têmpo em que nada pré-estabelecido como código de linguagem é possível.

\section{A semiologia do cinema baseada na teoria da imagem.}

As teorias da imàgem formuladas a partir das idéias de Peirce têm sido consideradas úm subsídio básico para a compreensão do 
cinema em termos semióticos. Procura-se definir um sistema de códigos para tratar a imagem, relacionando-a com a ciência geral da arte e o conjunto de significados da linguagem usual. A formulação semiótica da imagem, no entanto, tem-se mostrado bastante complicada. Pode-se destacar a este respeito, por exemplo, a tentativa de Santaella \& Nöth (1998) de estabelecer em termos semiológicos a diferença entre imagens como qualidade de signos que representam aspectos do mundo visível e como figuras puras e abstratas ou formas coloridas (p. 37). Subentende-se desta diferenciação que, na análise da imagem, há duas categorias de entendimento em jogo: a imagem como um conceito associado a signos é uma destas categorias; e a imagem como um conceito plástico é outra. No entanto, na afirmação de que a diferença entre ambas as maneiras de observação se refletirá, na semiótica da imagem, na dicotomia signos icônicos versus signos plásticos (p. 37), surge o problema de não ser utilizada a própria diferenciação estabelecida. Para esses autores, as qualidades da imagem por eles designadas "plástica", "pictorial" e "abstrata" estão associadas aos signos, e não se colocam dentro da segunda categoria de entendimento que eles mesmos estabeleceram para tais qualidades. Seria preciso que sua proposta diferenciasse corretamente a caracterização icônica que diz respeito à concepção da imagem como signo e sua caracterização plástica, que não é semiótica.

Dessa forma, a pintura puramente abstrata deveria ser concebida apenas em termos técnicos ou artísticos, formulados como jogo de cores, sombras e luz, fora da teoria geral dos signos. Não tem sentido afirmar, por exemplo, que a pintura abstrata mostra que imagens sem referenciais, ou seja, sem função icônica, podem ser simples signos plásticos (p. 37, grifo nosso). Na verdade, a pintura abstrata apresenta imagens que, a rigor, não podem ser conceituadas como signos plásticos, pois tal conceito envolve a noção de signo, o que pressupõe necessariamente a existência de uma função semiótica, no caso a icônica. Nas palavras de Peirce (1995, p.48),

[...] se existe algo que veicula informação e que, entretanto, de forma alguma se relaciona com ou se refere 
a algo com que a pessoa a quem esse algo veicula a informação tem, quando percebe a informação, a menor familiaridade, direta ou indireta - e essa seria uma espécie de informação bem estranha -, esse algo, nessa obra, não é chamado de Signo.

Além disso, tendo-se em conta que o conceito de signo plástico possibilita a análise semiótica de imagens que não representam coisa alguma [...], mas também imagens icônicas podem ser consideradas como signos plásticos (Santaella \& Nöth, 1998, p. 38), pergunta-se: como é possível a um signo não representar coisa alguma? Peirce deixou claro que um signo, ou representamen é aquilo que, sob certo aspecto ou modo, representa algo para alguém. $\mathrm{O}$ mesmo autor escreveu também que um signo dirige-se a alguém, isto é, cria, na. mente dessa pessoa, um signo equivalente, ou talvez um signo mais desenvolvido e completa: [...] para que algo possa ser um signo, esse algo deve 'representar', como costumamos dizer, alguma outra coisa, chamada seu Objeto, [...] (p. 46-7, grifos do autor).

Diante disso, chega-se à conclusão de que o conceito de signo plástico não tem fundamento algum. Ele se contradiz com o pensamento peirceano e em nada ajuda a compreensão semiótica da imagem. Este tipo de discussão mostra como as teorias sobre a imagem são imprudentes em sua interpretação sobre os próprios fundamentos em que se assentam.

Outra importante teorização semiológica sobre a imagem diz respeito às suas características como ícones. Sabe-se que qualquer coisa, seja uma qualidade, um existente individual ou uma lei, é Ícone de qualquer coisa, na medida em que for semelhante a essa coisa e utilizado como um seu signo (p. 52). Desta forma, as imagens, sendo semelhantes aos seus objetos de referência, tornamse signos icônicos, e se procuram elaborar definições a partir das suas características óptico-geométricas de conformação com a realidade: Uma imagem é uma superficie de tal modo tratada que um arranjo ótico delimitado a um ponto de observação se torna disponivel, contendo o mesmo tipo de informação que é 
encontrado nos arranjos óticos ambientais de um ambiente comum (Gibson, apud Santaella \& Nöth, 1998, p. 40).

O problema das definições da imagem em termos de sua iconicidade, como acima enunciado, está em elas serem muito gerais diante do grande conjunto de arranjos óptico-geométricos possíveis de serem produzidos por todas as mudanças de ponto de vista do observador sobre o ambiente determinado pelo objeto representado. Assim, duas fotografias poderão retratar um objeto de um mesmo ângulo de observação, no entanto, podem apresentar informações diferentes sobre as características óptico-geométricas deste objeto, de forma que seus efeitos visuais propiciam representações diferenciadas para o interpretante. A interpretação da imagem do ponto de vista icônico não é necessariamente única, pois as informações contidas no representamen sobre o objeto representado podem variar segundo a concepção artística do fotógrafo, desenhista ou pintor. Portanto, para estes, certo "arranjo óptico delimitado a um ponto de observação" não precisa conter o "mesmo tipo de informação que é encontrado" nos objetos representados. Aliás, é na técnica do arranjo óptico que se situa a qualidade artística de uma imagem.

As dificuldades geradas pela caracterização da imagem do ponto de vista icônico remetem às teorias sobre a convencionalidade:

O fato é que, para uma imagem representar um objeto, ela deve ser um simbolo, substitui-lo e a ele se relacionar; nenhum grau de semelhança é suficiente para estabelecer a relação de referência necessária. [...] Quase tudo pode representar todo o resto. Uma imagem que representa um objeto o denota [...]. Denotação é o núcleo da representação [...]. A relação entre uma imagem e o que ela representa é uma relação próxima, constituida pelo encontro de um predicado e um fato. (Goodman, apud Santaella \& Nöth 1998, p. 40)

A concepção convencionalista se fundamenta na idéia de que, tal como o signo lingüístico, o signo imagético é arbitrário e se comporta como um símbolo notacional, cujo sentido é dado por regras 
de interpretação pré-definidas, como na linguagem. Os logotipos utilizados pelo marketing, como coca-cola, por exemplo, são representantes típicos de imagens simbólicas convencionais. As relações de referência entre a imagem e seus objetos não são estabelecidas pelos graus de semelhança óptico-geométricas, como na teoria da iconicidade. Diversas imagens que mostram um objeto sob diferentes aspectos e tamanhos não nos deixam reconhecer, de forma homogênea, a disjunção ou diferenciação sintática ou semântica e, assim, a existência de um signo (Santaella e Nöth, 1998, p. 41). Aqui, a palavra signo deve ser substituída por simbolo, para que a citação tenha sentido, pois os signos icônicos se caracterizam justamente pelo fato de que a eles não pode ser atribuída uma sintaxe ou uma semântica explícita, mas nem por isso deixam de ser signos.

O problema da teoria convencionalista é que ela se aplica somente ao estudo dos símbolos imagéticos que, em oposição simultânea ao ícone e ao índice, se fundamentam na convenção social. Para a teoria convencionalista, não importa o meio físico sobre o qual a imagem é construída, mas, apenas, o aporte da sua simbologia extrínseca. Porém, a grande dificuldade da era da informação é entender a diversidade das mídias e, portanto, as teorias da imagem veiculadas.

\section{As dificuldades da tricotomia peirceana dos signos e a categorização semiológica do cinema}

A divisão dos signos em índices, ícones e símbolos é apenas uma das tricotomias peirceanas, havendo ainda mais duas outras possíveis. A primeira dessas diz respeito ao tipo de existência do signo em termos da sua realidade física, podendo ser: (1) meramente uma qualidade abstrata de um objeto, como a beleza representada na obra de arte; (2) existente concreto que se pode tocar fisicamente, como o gelo representando o frio; (3) lei geral que diz respeito às possibilidades existenciais lógicas de um ser ou objeto, como as idéias da matemática que estabelecem relações entre as qualidades reais 
dos objetos ou as idéias da lógica que estabelecem relações entre as suas qualidades abstratas.

No caso da divisão (1), ocorrem os chamados qualissignos, nos quais o signo não existe sozinho, e deve corporificar-se em seu objeto para ser interpretado; no exemplo da beleza incorporada à obra de arte, esta, de fato, não existe independentemente daquela. No caso da divisão (2), têm-se os sinsignos, que estão incorporados ao seu objeto, mas existem independentemente deste. De fato, o frio incorporado no gelo é uma qualidade física dos corpos a baixas temperaturas e pode-se perfeitamente sentir frio sem que nenhum gelo esteja presente. $\mathrm{Na}$ divisão (3), ocorrem os legissignos, que existem como formas do pensamento e não dizem respeito a qualidades ou realidades dos objetos. A relação de ordem $\mathrm{A}<\mathrm{B}$ é um exemplo de legissigno, estabelecida abstratamente pela mente humana, pois não está presente nem em A nem em B, mas apenas na comparação que o interpretante faz das suas qualidades. Assim, a dedução lógica não está presente em Sócrates nem no qualissigno mortal quando se diz: Todo homem é mortal; e Sócrates, sendo homem, conclui-se que ele tenha o atributo da mortalidade.

A outra tricotomia peirceana dos signos diz respeito à natureza da sua representação, definindo, portanto, os possíveis papéis do interpretante: (1) Rema é um signo de possibilidade qualitativa para o interpretante, ou seja, representa esta e aquela espécie de objeto possível; (2) Dicente ou Dicissigno é o signo que, para seu interpretante, possui existência real; e (3) Argumento é signo de lei para o interpretante. O Rema é um signo de possibilidade, como a beleza presente na obra de arte; o Dicissigno é um fato presente na natureza, como o frio que se sente no gelo quando se lhe interpõe a mão ou a mortalidade inerente aos seres vivos; e o Argumento é um signo de razão, somente possível pela ação do pensamento humano e que nunca pode ser visto como qualidade possível ou fato concreto.

A divisão tricotômica dos signos diz respeito a índices, ícones e símbolos e define o caráter social dos significados fornecidos pelo interpretante, ou seja: (1) os índices são signos que não precisam da presença do interpretante para existir; (2) já os ícones dependem em grande parte da presença do interpretante; e (3) os símbolos 
dependem totalmente da presença do interpretante para se constituir como signos.

Um signo é um ícone, um índice ou um símbolo. Um ícone é um signo que possuiria o caráter que o torna significante, mesmo que seu objeto não existisse, tal como um risco feito a lápis representando uma linha geométrica. Um índice é um signo que, de repente, perderia seu caráter que o torna um signo se seu objeto fosse removido, mas que não perderia esse caráter se não houvesse interpretante. Tal é, por exemplo, o caso de um molde com um buraco de bala como signo de um tiro, pois sem o tiro não teria havido buraco; porém nele existe um buraco, quer tenha alguém ou não a capacidade de atribui-lo a um tiro. Um símbolo é um signo que perderia o caráter que o torna um signo se não houvesse um interpretante. Tal é o caso de qualquer elocução de discurso que significa aquilo que significa apenas por força de compreender-se que possui essa significação. (Peirce, 1995, p. 74, grifos do autor)

A divisão tricotômica dos signos em ícones, índices e símbolos, da forma como estes são considerados na citação acima, conduz a uma dificuldade quando, na mesma página referenciada, lê-se que um signo é: "qualquer coisa que conduz alguma outra coisa (seu interpretante) a referir-se a um objeto ao qual ela mesma se refere (seu objeto), de modo idêntico, transformando-se o interpretante, por sua vez, em signo, e assim sucessivamente ad infinitum" (grifos do autor). Desta forma, o objeto e o interpretante são coisas que, juntamente com o signo, constituem uma teia de tal modo tramada qué nenhum dos três elementos pode ser concebido independentemente do outro. Se não houver um interpretante, portanto, uma coisa perde seu caráter de signo. Como é possível, então, que existam signos, os índices, cujo caráter não se perde se não houver interpretante? Como é possível aos ícones possuírem uma natureza que os torna significantes, ainda que seu objeto não 
exista? Os indivíduos de uma cultura que não conheça a geometria euclidiana jamais irão associar um risco de giz a uma linha reta; e, ao longo do desenvolvimento psicobiológico, as crianças, antes de "aprenderem" seu significado como sendo uma linha reta, percebem que se trata apenas de um risco de giz.

Acontece, com efeito, que, como a percepção é constituída em contato diretó com o objeto, ao passo que a imagem intervém em sua ausência, o espaço perceptivo é construido muito mais rapidamente do que o espaço representativo: ele atinge mesmo um hível já projetivo e quase métrico no momento em que a representação figurada tem inicio e permanece na construção, e em parte na reconstrução, das relações topológicas elementares. Há, portanto, um espaço, e mesmo de alguns anos, entre as duas construções, perceptiva $e$ representativa, malgrado a analogia de seus processos evolutivos, de tal sorte que, se não percebemos a dualidade dos planos, temos a ilusão de que a elaboração do espaço começa com as formas euclidianas simples. Ora, quando as observamos, mais ou menos na idade de 2 a 4 anos, as formas euclidianas são ao mesmo tempo derivadas, do ponto de vista perceptivo (porque preparadas por um desenvolvimento que começa desde as primeiras semanas de existência), e não ainda assimiladas pela representação (que trabalha sobre suas formas perceptivas complexas, mas por meio de relações muito mais elementares). Portanto, é indispensável dissociar o espaço perceptivo do espaço representativo, para fornecer uma teoria adequada à intuição geométrica. (Piaget \& Inhelder, 1993, p. 471-2)

Não é sem razão que Saussure restringiu a noção de signo, limitando-o ao símbolo de Peirce. Mas este não é, no entanto, o momento para discutir as conseqüências das dificuldades da teoria peirceana, desde que se pretendia apenas apontar uma delas. Importa 
aqui verificar como é que, dentro da proposta da análise semiológica, o cinema pode conter os três modos de signo, ou seja, índices, ícones e símbolos. Já sabemos que o cinema possui em maior grau os elementos indiciais, e, em menor grau, os elementos icônicos, mas com quase nada dos simbólicos, pois não contém um código de significados pré-estabelecidos.

Para nós, as categorias de signos do cinema se apresentam do seguinte modo: (1) Como um qualissigno, na medida em que as imagens em si representam ícones que causam "sensações" no espectador interpretante; (2) um sinsigno icônico que se apresenta como imagem semelhante à vida real presente, mas que, na verdade, age modificando a referência da dualidade existente entre o passado e o futuro; (3) um sinsigno indicial remático, propiciando a experiência direta de um objeto representado na fala por meio da imagem; (4) um sinsigno dicente, propiciando informações complementares por meio de efeitos especiais obtidos pela montagem da fita; (5) um legissigno icônico, estabelecendo uma lei geral que caracteriza uma trama entre personagens que corporificam, por exemplo, o bem e o mal; (6) um legissigno indicial remático, na medida em que a evolução da trama entre os personagens é acompanhada pela mudança de cenário e adaptações; (7) um legissigno indicial dicente, na medida em que dispõe de meios para escolher a melhor representação do enredo; (8) um símbolo remático ou rema simbólico, enquanto a imagem e a fala podem ser entendidas uma em relação à outra de forma sincronizada; (9) um símbolo dicente, na medida em que a fala está internalizada na imagem filmica; e (10) um argumento, que recebe o nome de script nas mãos do diretor cinematográfico.

Não podendo o cinema constituir-se como uma linguagem codificada, a crítica e a estética cinematográficas também não podem se dissolver no campo da teoria geral dos signos, impondo limites à abordagem semiológica. Desta forma é que André Bazin, um dos fundadores do histórico Cahiers du Cinema, na década de 30, destaca que o elo mais forte do filme com o espectador é do tipo existencial, o que para Peirce é a característica determinante do signo indicial. Enquanto Peirce se ocupou de desenvolver uma lógica dos signos, 
Bazin (1991) procurou fundar uma estética baseada na fotografia. $O$ que nos afeta na fotografia de uma flor ou de um floco de neve é a beleza natural do objeto representado, de forma que a natureza é sempre fotogênica. Entretanto, ao mesmo tempo em que se aproxima de Peirce com relação à ontologia da imagem fotográfica, Bazin afasta-se dele quando se recusa a fundar sua estética na semiologia. A estética de Bazin reivindica a primazia do objeto sobre a imagem, a primazia do mundo natural sobre o mundo dos signos. As categorias filmicas de Bazin obedecem a dois planos estéticos excludentes diferenciados segundo o juízo de valor fornecido pela fidelidade à natureza. De um lado, está o realismo de Godard e Rossellini e, de outro, o expressionismo de Hollywood. O realismo se firmou na técnica espontânea e ingênua do cinema, enquanto o expressionismo desenvolveu formas elaboradas de montagem. No início da história do cinema, os filmes de Feuillade representavam a tendência realista que evoluiu nos anos 20 com películas de Flaherty, Von Stroheim e Murnau. Nessa mesma época, os filmes de Eisenstein, Kulechov e Gance representavam a tendência expressionista.

O diretor mais importante dos anos 30, na perspectiva de Bazin, foi Jean Renoir, que reformulou a função do enquadramento na composição cinemática, inspirando-se na tradição do impressionismo francês, mas contrastando-se ao mesmo tempo com o princípio da montagem de Eisenstein. Renoir criou a idéia de recadrage (reenquadramento): movimentos laterais da câmera que capturavam a realidade de uma forma contínua em vários de seus ângulos frontais. Este diretor olhou para além dos recursos fornecidos pela montagem e descobriu o segredo de uma forma filmica que permitia capturar a realidade sem cortar o mundo em pequenos fragmentos, revelando significados escondidos sem perturbar a unidade natural do mundo. Será esta a perspectiva que se pretende mostrar a seguir como representando a busca de padrões estéticos específicos da linguagem cinematográfica presentes em todo o seu percurso gerativo, inclusive durante o período correspondente à semiologia. Tais especificidades estarão, no entanto, além da estética fundamentada na concepção puramente fotográfica proposta por Bazin, contrapondo-se a esta o alcance 
técnico e artístico do movimento da imagem captado pela câmera, categoria primordial do cinema.

\section{Walter Benjamin e a estética da obra cinematográfica como produto técnico}

O célebre texto de Benjamin (1980) mostra como as formas de reprodutividade técnica da obra de arte que se desenvolveram nas primeiras décadas do século XX modificaram profundamente os conceitos de representação estética construídos em decorrência da arte do passado. A fotografia, conhecida desde o século XIX, tem a inusitada capacidade de destacar aspectos da realidade que escapam ao olho e são apenas passiveis de serem apreendidos por uma objetiva que se desloque livremente a fim de obter diversos ângulos de visão; graças a métodos como a ampliação ou a desaceleração, pode-se atingir a realidades ignoradas pela visão natural (p. 7). O objeto representado perde assim a sua originalidade e pode levar à produção de situações em que ele jamais seria encontrado, como uma paisagem gravada e modificada pelas técnicas de revelação. Para Benjamin, o que diferencia substancialmente a produção artística no passado da fotografia e do cinema atuais é que, nestes, o conceito de reprodutividade técnica é inerente à própria concepção de obra de arte. Diversamente do que ocorre na literatura e na pintura, a reprodutividade técnica não é simplesmente uma condição exterior a facultar a difusão maciça de um filme, mas a sua técnica de reprodução funda diretamente a sua técnica de produção. Ela não apenas permite, de modo mais imediato, a produção maciça do filme, mas exige-a. As despesas de produção são tão altas que impedem ao indivíduo adquirir um filme como se comprasse um quadro. (p. 11)

Benjamin julga que o polêmico debate protagonizado no século XX pelos pintores e fotógrafos sobre o valor estético respectivo de suas obras dá-lhe a impressão de responder a um falso problema e se basear numa confusão (p. 13). O debate não levava em consideração o significado histórico da inovação 
técnica, portanto, a análise dos próprios meios de produção material da sociedade industrial que se formaram desde a transição do feudalismo para o capitalismo, tema tão bem estudado por Marx, do qual Benjamin era afeto. Mas o século que assistia a éssa evolução foi incapaz de perceber a alteração funcional que ela gerava para a arte. E tal conseqüência, até durante lóngo tempo, escapou ao século $X X$ que, no entanto, viu o cinema nascer e se desenvolver (p. 13). Antes de indagar se a invenção da fotografia não transformou o carảter geral da arte, os teóricós gastaram-se em futilidades analíticas que em nada contribuíram para com o entendimento da revolução que se sucedeu. Os teóricos do cinema sucumbiram no mesmo erro. Contudo, os problemás que a fotografia colocara para a estética tradicional não eram mais que brincadeiras infantis em comparação com aqueles que o filme iria levantar ( $\mathrm{p}, 14)$.

A perspectiva apontada por Benjaminin em relação às transformações que o cinema incorporou à conceituação estética tradicional sobre a arte levaram-no a citar as previsões de Franz Werfel:

O cinema ainda não aprèndeu seu verdadeiro sentido, suas verdadeiras possibilidades. Elas consistem no poder que ele detém intrinsecamente de exprimir, por meios naturais, e com uma incomparável capacidade de persuasão, o feérico, o maravilhoso, o sobrenatural. (Werfel apud Benjamin, 1980, p: 14)

A Obra de Arte na Era de sua Reprodutividade Técnica é um texto publicadoem 1936 è Benjamin náo poderia prever que, na segunda metade do século, o surgimento da televisão banalizaria o cinema e que, no fim, o apárelho de vídeo acábaria por tornar possível a um indivíduo adquirir filmes e levá-los para ser reproduzidos na sua própria casa. A técnica de reprodução da obrả cinematográfica estava, enfim, ao alcance de cada um è o culte que exprime $a$ incorporação da obra de arte a um conjunto de relações tràdicionais (p. 10) passou a ser praticado no altar doméstico cujo centro é o aparelho de televisão. 
$\mathrm{O}$ valor estético da. arte funda-se sobre [...] um ritual secularizado - através do culto dedicado à beleza - mesmo sob as formas mais profanas (p. 10). Este culto à beleza apareceu na época do Renascimento e guarda a marca reconhecível de sua origem, mesmo diante do primeiro abalo que sofreu após os três séculos em que sua função ritualística permaneceu intocável. Para Benjamin, quando surgiu a primeira técnica de reprodução verdadeiramente revolucionária - a fotografia; que é contemporânea dos primórdios do socialismo - os artistas pressentiram a aproximação de uma crise que ninguém - cem anos depois - poderá negar ( $\mathrm{p}$. 10). Tal crise teve como combustivel a polêmica sobre se a fotografia era ou não uma forma autêntica de arte. Os que postulavam contra o reconhecimento da fotografia como arte reagiram, professando ' $a$ arte pela arte', ou seja, uma teologia da arte ( $\mathrm{p} \cdot \cdot 10)$. O surgimento da fotografia começa a empurrar $0^{\circ}$ valor de culto - em todos os sentidos - para segundo plano (p. 13). Benjamin vê o retrato fotográfico como o culto da recordação dedicada aos seres queridos, afastados ou desaparecidos e, neste aspecto, o valor de culto da imagem encontra o seu último refúgio (p. 13).

Os debates em torno do valor estético do cinema como obra de arte são ainda mais polêmicos do que os debates em torno da fotografia, da qual ele é tecnicamente herdeiro. No cinema, o valor do culto estaria, segundo Benjamin, relegado a um plano ainda mais interior que o da fotografia. Para ele, o fato da atuação artística no cinema requerer uma ampla mediação de técnicas de reprodução implica que a performance do ator seja potencialmente desrespeitada. A câmera registra nada mais do que tomadas em relação a essa performance para a posterior montagem do filme. A montagem, por sua vez, sendo feita a partir da disponibilidade dos elementos móveis que a câmera pode captar, e tendo por base outros elementos, tais como o primeiro plano, muitas vezes, despreza as partes mais importantes da performance interpretativa do ator. Além disso, não há, como no caso do ator teatral, a possibilidade de adaptar a sua atuação às reações dos expectadores no decorrer da representação (p. 15): Não há qualquer contato pessoal do intérprete com o público e este só consegue penetrar na aura do ator se penetrar 
na aura do aparelho. Mas, como não pode fazer isso, o público toma a mesma atitude do aparelho: examina um teste. Não se trata de atitude à qual se possam submetèr os valores de culto (p.15).

É dificil entender a metáfora do" público entrando no aparelho cinematográfico", e se pode pensar que, por meio do cinema, não é possível ao expectador atingir a aura do ator. Porém, levando-se em conta que, à época de Benjamin, as multidões atraídas pelos filmes já reverenciavam como deuses os astros da tela, não há como argumentar contra o fato de que o cinema aprofundou as formas de culto à beleza, surgidas com a revolução artística protagonizada na História com o Renascimento. Mais tarde, o advento da televisão e do vídeo revolucionaram tanto a condição de reprodutividade da arte cinematográfica que a aparelhagem de reprodução surgiu como um fenômeno presente de forma massiva nas casas das famílias da sociedade moderna. Os aparelhos de reprodução encontrados nas moradias do homem. contemporâneo têm uma função semelhante àquela do altar doméstico primitivo de ídolos religiosos: por meio deles, é possível afastar-se do interior da casa e estabelecer formas representativas de controle sobre o mundo externo. O que caracteriza o cinema não é apenas o modo pelo qual o homem se apresenta ao apàrelho, é também a maneira pela qual, graças a esse aparelho, ele representa para si o mundo que o rodeia(p. 22).

A idolatria do público com relação aos astros do cinema é muito maior do que a existente em relação ao teatro. Diante disso, torna-se possível recolocar a metáfora benjaminiana sobre o público do cinema como o olho se confundindo com a objetiva da câmera. Mas Benjamin era cético em relação ao valor estético da arte representada pelo ator de cinema, quando comparava a interpretação cinematográfica com o teatro. Ele escreveu que o intérprete de um filme

[...] sente-se estranho frente à sua própria imagem que lhe apresenta a câmara. De inicio, tal sentimento se parece com o de todas as pessoas, quando se olham no espelho. Mas, dai em diante, a sua imagem no espelho separa-se 
do individuo e toma-se transportável. $E$ aonde a levam? Para o público. Trata-se de um fato do qual o ator cinematográfico permanece sempre consciente. Diante do aparelho registrador, sabe que - em última instância é com o público que tem de se comunicar. Nesse mercado dentro do qual não vende apenas a sua força de trabalho, mas também, a sua pele e seus cabelos, seu coração e seus rins, quando encerra um determinado trabalho, ele fica nas mesmas condições de qualquer produto fabricado. [...] Na medida em que restringe o papel da aura, o cinema constrói artificialmente, fora do estúdio, a 'personalidade do ator.'; o culto do astro, que favorece ao capitalismo dos produtores e cuja magia é garantida pela perssonalidade que, já de há muito, reduziu-se ao encanto corrompido de seu valor de mercadoria. (p: 178 , grifo do autor)

A confecção de um filme utiliza um conjunto de equipamentos e atividades totalmente estranhos à prática do teatro. A circunstância representada pelas máquinas de filmar, os aparelhos de iluminação, o estado-maior dos assistentes etc. torna superficial e sem importância todas as analogias que se poderiam erguer entre a filmagem de uma cena em estúdio e sua execução no teatro ( $\mathrm{p}$. 19). Com isso, Benjamin admite que a forte magia contida no culto ao cinema vai além da possibilidade oferecida pela ação interpretativa dos atores, que são desprovidos de sua aura pelas circunstâncias do estúdio. $O$ fascínio do público pelo cinema consiste no efeito sobre a percepção de possibilidades como se seqüências de imagens de uma mesma cena pudessem ser vistas de vários ângulos diferentes. As técnicas de variação dos ângulos de tomada disponibilizam para a montagem do filme uma ampla gama de material e a habilidade dos bons diretores reside exatamente em saber quais seqüências produzem os melhores efeitos estéticos. Alargando o mundo dos objetos dos quais tomamos conhecimento, tanto no sentido visual quanto auditivo, o cinema acarretou, em conseqüência, um aprofundamento da percepção (p. 22). 
A interpretação dos atores não é, efetivamente, o ponto fundamental de um filme, pois elencos medíocres podem produzir grandes obras, em decorrência da habilidade dos diretores. Por isso, o glamour dos atores é construído fundamentalmente fora das telas, pois em decorrência da obra do cinema, o homem deve agir com toda a sua personalidade viva, mas privado de aura. Pois sua aura depende de seu hic et nunc (p. 16). Em uma montagem teatral, a aura do personagem é inseparável do ator e é percebida localmente pelo público. Mas, no cinema, a atuação é realizada de acordo com as condições impostas pela aparelhagem que substitui o público. $\mathrm{O}$ desempenho do papel pelo ator não é realizado ininterruptamente, mas, sim, em uma série de seqüências isoladas. Arnheim (apud Benjamin, p. 16) escreveu que, no cinema é quase sempre interpretando o mínimo que se obtém mais efeito [...]. A última escala do progresso consiste em reduzir o ator a um acessório escolhido pelas suas características [...] e que se utiliza funcionalmente.

Para Benjamin, as seqüências cinematográficas registradas pela câmera, montadas e depois reproduzidas pelo projetor, apresentam um número bem maior de perspectivas do que as oferecidas pelo teatro e pela pintura, e facilitam ao expectador alargar sua percepção física. A importância capital do cinema reside no fato de favorecer a compenetração mútua da arte e da ciência, propiciando à percepção um levantamento incomparavelmente mais preciso dos elementos constituintes da realidade. Esta, quando vista através dos primeiros planos e sob a direção engenhosa da objetiva, sublinha detalhes insuspeitos nos ambientes familiares. $O$ espaço se alarga dentro do primeiro plano e o movimento pode ser aprisionado através do relenti - a câmera lenta.

As técnicas de filmagem e montagem quando bem aplicadas produzem seqüências do roteiro que, ao serem projetadas, apresentam formas desconhecidas à ação consciente do olhar, abrindo a experiência do inconsciente visual. Uma das tarefas essenciais das novas formas de expressão da arte, explica Benjamin, é suscitar determinada indagação num tempo ainda não maduro para que se recebesse plena resposta (p. 23). A história de cada forma de 
arte mostra que há momentos em que as crises de ordem estética somente podem ser superadas em decorrência da modifịcação do nível técnico, quer, dizer, mediante uma nova forma de arte (p. 24). O cubismo e o. futurismo foram movimentos artísticos que surgiram concomitantemente ao cinema e ambos aparecem como tentativas insuficientes da arte para assimilar, à maneira deles, $a$ intrusão de aparelhos dentro da realidade (p. 25). Mesmo não utilizando diretamente as tecnologias do cinema como fundamento de produção artística, tais movimentos sofreram a sua influência, pois valorizam os efeitos ópticos, da mesma forma como um filme sobre eles repousa.

A visão estética de Benjamin sobre o cinema como produto técnico está amplamente consignada em seu texto, mas à sua época os elementos históricos desta expressão artística pouco podiam dizer sobre como ela evoluiria até o fim do século. Desta forma, a perspectiva analítica de Benjamin se volta para o caráter do cinema como diversão de massa, matriz de onde emana, no momento atual, todo um conjunto de atitudes novas com relação à arte (p. 25). Ao postular o aspecto político como prioritário na análise estética do cinema, mesmo sem desbancar os efeitos da técnica, Benjamin os remete em seu texto a um segundo plano de importância. Para ele, as mudanças sucessivas de lugares e ambientes provocam choques no espectador, que impedem qualquer associação no espírito e favorecem o gosto da massa pelo cinema como pura diversão. $A$ pintura convida à contemplação; em sua presença, as pessoas se entregam à associação de idéias. Nada disso ocorre no cinema; mal o olho capta uma imagem, esta já cede lugar a outra e o olho jamais consegue se fixar (p. 25).

A diversão se contrapõe à idéia de arte, porque esta exige a concentração e um mergulho interior "como aquele pintor chinês cuja lenda narra haver-se perdido dentro da paisagem que acabara de pintar" (p. 26)..No caso da.diversão, é a obra de arte que penetra ña massa e causa um choque estético de natureza depreciativa, correspondente ao estilo de vida cada vez mais perigoso do homem contemporâneo. A necessidade de se submeter a efeitos de choque constitui uma adaptação do homem aos perigos que o ameaçam 
(p. 25). $\mathrm{O}$ estado de distração em que o cinema coloca a massa corresponde à estetização da vida política que culmina com a guerra. A guerra, e só ela, permite fornecer um motivo para os maiores movimentos de massa [...] e só a guerra permite mobilizar todos os recursos técnicos da época prêsente (p.:27). A guerra foi glorificada pelos regimes fascistas da primeira metade do: século e correspondia, na acepção de Benjamim, a um ideal político de mobilização da massa que lhe permitia exprimir-se sem modificar o regime de propriedade que paralisava as forças produtivas e levava à sua crescente paralisação. A respeito desta mobilização política, da qual as formas perceptivas da arte engendradas pelo. cinema contribuíram significativamente, assim se expressou Benjamin:

Eis como se pode répresentar a estética da guerra, hoje em dia: já que a utilização normál das forças produtivas está paralisada pelo regime da propriedade, o desenvolvimento dos meios técnicos, do ritmo das fontes de energia, voltam-se para um uso contra a natureza. Verifica-se através da guerra quie, devido às destruições por ela empreendidas, a sociedade não estava suficientemente madura para fazer da técnica o seu órgão; que a técnica, por seu turno, não estava suficientemente evoluida a fim de dominar as forças sociais elementares. (p. 28)

A massa mobilizada politicamente pelo fascismo esperava da guerra a satisfação artística de sua percepção sensível, modificada pela técnica, e na qual a destruição correspondia ao gozo estético. Essa idéia presente no parágrafo final do epílogo do texto de Benjamin parece soar como uma profecia, tendo em conta os acontecimentos que se sucediam na Europa e que conduziriam breveménte à eclosão da Segunda Guerra Mundial. A idéia suscita também a visão melancólica do mundo que caracterizou a vida de Benjamin e que o levou a suicidar-se na fronteira entre a França e a Espanha em 1940, não resistindo à tensão psicológica causada pelo temor à Gestapo, a terrível corporação nazista que o perseguia. $\mathrm{O}$ texto é um marco na 
história da teoria crítica desenvolvida pelo grupo de Frankfurt, do qual Benjamin foi um dos principais representantes.

Não são poucas as limitações que podem ser apontadas na percepção expressa no texto sobre o cinema, algumas delas decorrentes da época em que foi escrito, quando a televisão ainda não existia. Esta, conforme já apontado aqui, ampliou profundamente as possibilidades técnicas de reprodução do material cinematográfico. Extraindo do cinema os fundamentos gerais de toda a sua produção, a TV exibe em larga escala os próprios filmes. Por meio do vídeo, tecnologia mais recente, passou a permitir que um indivíduo pudesse comprar um filme e levá-lo para ser reproduzido em casa, alterando desta forma a relação de posse deste indivíduo para com a obra de arte e, conseqüentemente, banalizando a sua percepção estética. A televisão possui um caráter muito mais forte do que o cinema tradicional no que diz respeito ao controle político do pensamento da massa. A exposição intensiva dos governantes nos meios de comunicação passou a ser a técnica primordial de todos os regimes políticos, não só os fascistas. $O$ rádio e o cinema não modificam apenas a função do ator profissional, mas - de maneira semelhante - a de qualquer um, como o caso do governante, que se apresente diante do microfone ou da câmera (p. 17). O que mais importa é a própria exposição em si mesma do político, esvaziando o conteúdo das formas democráticas de governo, dai a existência de uma nova seleção diante do aparelho: os que saem vencedores são o vedete e o ditador (p. 17). E, com a televisão, esse processo pode ser levado ao extremo.

Outra limitação do texto é que a análise estética nele contida culmina com uma visão restrita apenas ao formalismo do campo sociológico e político. $O$ cinema é abordado por meio da linguagem oriunda de suas especificidades técnicas para explicar como ocorre sua influência sobre o pensamento político da massa. $O$ texto utiliza fluentemente o vocabulário desta linguagem, contido em determinados conceitos, tais como o enquadramento, a projeção em câmera lenta etc., estabelecendo um sistema de códigos capaz de explicitar a percepção artística do expectador. Pode-se dizer, assim, que Benjamin tinha uma concepção gramatical da linguagem do cinema, como mais 
tarde o faria a semiótica, mas tudo isso está situado de forma subjacente nos níveis profundos da sua escrita. Para ele, todos os recursos técnicos da época foram mobilizados pelos regimes fascistas em direção à guerra. Ele não vê que, utilizando outros recursos de mobilização da massa, o fascismo seria o mesmo sem o cinema. Portanto, a estética resultante do cinema não se traduz apenas na linguagem política, mas também em outras esferas possíveis que existem separadámente, como certos teóricos procuraram mostrar.

\section{Pontos e contrapontos na semiologia do cinema de Christian Metz}

A arte cinematográfica envolve uma complexa estrutura econômica para ser produzida em escala industrial e distribuída no mercado de entretenimento: exige uma sofisticada aparelhagem técnica para gravações, montagens e projeções; suscita uma ampla rede social de comunicą̧ão para a compreeñão de suas características estéticas, dos efeitos psicológicos e de implicações políticas; motiva uma vasta articulação conceitual de natureza antropológica que estuda sua pertinência como veículo cultural; e, atualmente, desenvolve uma forma renovadora de reflexão metodológica e lingüística destinada a estabelecer os fundamentos de sua abordagem científica. Christian Metz (1980) é o teórico que melhor assumiu esta última perspectiva, propondo uma semiologia aplicada ao "fato filmico", preocupando-se não com o todo do "fato cinematográfico"' presente no pluralismo estrutural envolvido na complexa rede de relações do cinema, mas apenas e precisamente, com o fenômeno do "discurso significante localizável" na "forma e substância" tanto do "conteúdo" quanto da "expressão" da linguagem filmica.

Metz justifica sua proposta argumentando que nenhuma disciplina foi:ainda capaz de entender o filme como um "objetosignificante total", o que somente a análise semiológica pode fazer. Tal empreendimento se apóia em dados (não em métodos) emprestados da sociologia do fato filmico, da sua psicologia, história, 
estética etc., objetivando fornecer um "saber coerente e unitário". O tipo específico de semiologia proposto por Metz distingue o "cinema" do "filme". para fazer deste último o seu objeto de estudo. Quanto ao método, ele utiliza a análise dos filmes como "textos" que formam unidades discursivas e "sistemas" de códigos, cuja pesquisa se processa em termos do pluralismo necessário ao "indispensável". tratamento da fragmentação (p. 7-21).

Um problema fundamental posto à semiologia de Metz diz respeito à dificuldade da própria estrutura de significação, criada da distinção entre os conceitos de cinema e filme.

Em uma perspectiva semiológica, interessa dispor de dois termos (simples e flexiveis) para distinguir essas unidades concretas de discurso, cada qual denominada filme e apresentando-se como uma totalidade singular suscetivel de ser diretamente provada, dessa espécie de conjunto ideal que tem por nome "cinema", soma virtual de todos os filmes $e$, por outro lado, o suposto lugar para onde confluem e se organizam diferentes estruturas de significação ('processos', 'recursos expressivos', 'figuras', etc.) que - mesmo se.cada filme as põe em prática e as agrupa à sua maneira, mesmo se cada filme só atualiza uma parte - não são, em seu fundamento, menos comuns, potencialmente, a todos os filmes, na medida em que precisam uma combinação geral onde cada filme se inserirá e que está ligada à adoção geral do próprio veículo cinematográfico. (p. 24, grifo do autor)

Nessa distinção, as idéias de filme e cinema não permitem que os princípios indutivos e dedutivos da lógica elementar sejam utilizados como formas do pensamento semiológico, pois as variações da. parte e do todo são sempre simultâneas. Cada nova parte do sistema proposto - o filme - contém unidades concretas percebidas. pelo discurso semiológico que atualizam as estruturas de significação do conjunto formado pelo todo - o cinema - de forma que não parece haver fundamentos potencialmente comuns determinando "uma 
cómbinação geral onde cada filme se inserirá", como citado. Na verdade, os princípios de regularidade presentes em cada unidade fílmica só dependem dos fundamentós do veícúlo cinematográfico como um 'todo em uma perspectiva bastante restrita." Até mesmo para filmes do mesmòo "gêrero", torna-se difícil estabelécer uma estrutura de significação comum no sentido semiótico. É por isso que Metz escreve:

[...] é claro que a semiologia:dita do cinema se estabelece essencialmente do lado do 'fato filmico'. 'A despeito das inevitáveis interferências, zonas de superposição e outros ricochetes metodológicos, ela não poderia aspirar a esclarecer utilmente o estudo do 'fato cinematográfico', ao menos de maneira frontal è no atual estado das pesquisas (p. 11)

É viável, no entanto, que a aspiração de estudar os códigos comuns presentes nos distintos gêneros cinematográficos seja um encaminhamento natural da pesquisa sémiológica. Metz levanta esta possibilidade em seu trabalho, mas de forma superficial; porque sua semiologia está baseada em uma redução fornecida pelo par terminológico cinèmalfilme, no qual [...] o que, em todos os empregos (inclusive os mais correntes), se:denomina 'cinema' não é apenas a noção de uma totalidade dos aspectos ligados ao filme, [...] é também a totalidade dos própriós filmes, ou ainda a totalidade dos traços que, nos filmes, são considerados característicos de uma certa 'linguagem' pressentida (p. 23-4, grifo do autor). Desta forma, a semiótica não utiliza sistematicamente a noção de gênero para dividir a totälidade dos filmes em classes de semelhanças estilísticas ditadas por traços comuns, como é feito no estudo de outras artes. Metz propõe que existe entre cinema e filme a mesma relação existente entre literatura e livio, entre pintura e quadro, entré escultura é estátua etc [...] (p. 24). Nesta idéia, a literatura tem o mesmo sentido metodológico (não semiológico) dé cinema e o livro equivale ao filme. Mas, se o estudo da literatura propõe como fundamental a divisão de suas unidadès de significação 
representadas pelos livros em gêneros distintos, tais como a poesia; 0 romance e o conto, por que as teôrias do cinema não fazem o mesmo?

Metz é crítico em relação à idéia de homogenéidade contịda na "linguagem" unitária do "cinema". como códigoúnico e soberanó coextensivo à. tòtalidade do material semiológico apresentado nos filmes.' Os perigos! são claros; pois o 'cinema', assim 'entendido, torna-se um código único e total [...], com o risco de chamar esse código: de 'linguagem': vocabulário em que se mostra o desejo confuso, que é próprio dessa concepção, dè não renunciar

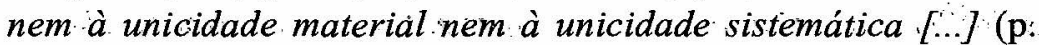
30). Mas, ao mesmo tempo, os códigos foram planejados para ser homogêneos e suia homogeneidade não é sensorial; mas da ordem da coerência lógica, do poder explicativo, do esclarecimento; da capacidade generativa (p. 31).

No atual estado da pesquisa semiológica, os códigos ainda não constituem sistemas formais em um sentido lógico pleno,'mas são todos considerados por Metz como unidades que aspiram à formalização. $E$ por isso que a correspondencia biunívoca entre os códigos e os conjuntos de mensagens fisicamente semelhantes [os gêneros] não apresenta de modo algüm um estado de fato necessário e permanente, nem mesmo simplesmente freqüente ( $p$. 31). Por outro lado, os esquemas literários desempenham um papel importante na construção dós filmes: [...] trata se definitivamente de sistemas que, enquanto sistemas, ‘são mais:ou menos semelhantes através dos diferentes conjuntós de ménsagens fisicamente homogêneas (p. 32, grifo do autor). Ora, na literatura os conjuntos de mensagens semelhantes contidas em seus gêneros são mais do que simplesmente uma necessidade lógica, tratando de realidades impostas pela natureza empírica - física - das mensagens dos livros. Desta forma, a lógica da homogeneidade dos códigos está longe de ser resolvida pela semiologia do cinema, pois ao mesmo tempo em que esta homogeneidade é fundamental para dar coerência e unicidade às mensagens contidas nasunidades fílmicas, ela não é de modo algum necessárià e permanènte!

Um filme é umà entidade específica, diferente de um livro e surge sempre como objèto de uma espécie particular; mas, ao mesmo 
tempo, explica Metz, é um erro de muitas teorias pretender de forma imediata e ingênua que as especificidades dos traços físicos do significante, como a visualidade ou a mobilidade, representem um fato semiológico, pois tais traços, visto que sua definição foi formulada em termos sensoriais, caracterizam inevitavelmente todos os filmes, e não poderiam distinguir alguns deles ${ }^{\star}[\ldots] \cdot(\mathrm{p}$ : 47): Pretender que 'o cinema é arte do movimento', não pode significar, não importa o que se tenha dito, enunciar uma das componentes da especificidade profunda do cinema, visto que significa enunciar uma das componentes de sua especificidade mais superficial e manifesta, e visto que todos os filmes sé movimentam (p. 48). A imagem em movimento não interessa, desta forma, à "linguagem cinematográfica" como fato do discurso semiológico, mas apenas à "especificidade cinematográfica", na medida em que se opõe a qualquer estrutura intrinsecamente não cinematográfica.

Quais seriam, então, as entidades que formam as estruturas das configurações significantes propriamente ditas da linguagem cinematográfica? Tais entidades pertencem, segundo Metz, ao plano. das configurações não específicas, presentes na "matéria de expressão" do cinema e que não se confundem com as suas particularidades físicas. A estrutura das configuraçõès significantes propriamente cinematográficas não é definida diretamente por critérios materiais; mas em termos de códigos, mesmo se a especificação dos códigos não puder, por sua vez, operar-se fora das considerações de certos traços da matéria do significante [...] (p. 48, grifo do autor).

Nesse ponto, o discurso semiológico começa a percorrer um caminho conflituoso, pois ao mesmo tempo em que a linguagem cinematográfica evita os tropeços das especificidades materiais, seus códigos não podem se constituir independentemente delas. Para contornar o problema, entre todos os fatos percebidos que podem ser batizados de cinematográficos, Metz,adota como ponto de interesse da semiologia apenas o que pode ser especificamente entendido como filmico. O filmico é o que pertence ao discurso significante (à mensagem) que é o filme como desenrolar percebido e como 
objeto de linguagem (mas que não é o 'filme', lembremos, como fita flexivel e enrolada em uma caixa redonda) (p. 53). Desta forma, Metz resolve o problema terminológico, mas não o semiológico, pois, afinal, continua sem resposta a pergunta: quais os códigos da configuração significante pertencentes à linguagem implícita no fenômeno filmico?

O uso espontâneo da palavra "filme" refere-se ao fenômeno da mensagem existente em uma unidade filmica particular e $a$ combinaçãa de vários códigos no interior de uma mesma mensagem nada mais é do que a estrutura dessa mensagem (p. 62). Mas, ao mesmo tempo, os códigos são objetos do mundo físico e permanecem sempre distintos das mensagens que dele decorrem. Assim, não podendo apreender o sistema de códigos das mensagens implícitas no fenômeno filmico, a semiologia precisa romper a dualidade do par terminológico cinema/filme.

[...] existe uma espécie de abuso, que se pode julgar inoportuno, mas que tem suas, próprias regras; estas prevêem que a possibilidade de substituição de 'cinema' $e$ 'filme' é unilateral; 'filme' não é substituivel por 'cinema', mas 'cinema' é substituivel por 'filme' [...]; a idéia de código está mais nitidamente presente em 'cinema' do que a de mensagem em 'filme': assim também 'cinema' acha-se excluido quando se deseja falar da mensagem, enquanto que 'filme' está apto a designar o fato de código e o fato de mensagem a um só tempo, ou pelo menos não exclui o código tão nitidamente quando 'cinema', a mensagem; 'filme' está pois disponivel em todos os casos, enquanto que 'cinema' só é passivel de uso quando se fala do código: é por isso que 'filme' sempre pode substituir 'cinema' sem que a reciproca seja verdadeira. $\left(\mathrm{p}_{., 6}, 67-8\right)$

Essa zona de interseção torna o empreendimento semiológico plausível, considerando ainda que todo fato cinematográfico é também um fato filmico, mas não o inverso. Assim, elementos típicos do fato cinematográfico, como os enquadramentos, as figuras de montagem, 
os movimentos da câmera, as ligações etc. são também fílmicos; podendo ser considerados como códigos semiológicos gerais por se apresentarem distintamente à mensagem filmica e estarem associados uns aos outros em uma lógica coerente e sempre tácita. $O$ princípio da montagem alternada, por exemplo, é concebido no filme como uma figura capaz de ocupar um segmento determinado da fitaimagem, e no cinema como uma figura [...] que realiza uma das possibilidades lógicas autorizadas por uma combinatória espaço-temporal puramente ideal (p. 69). Metz descobre, assim, a natureza dos códigos fílmicos: eles são os elementos que pertencem ao conjunto das realizaçṍes lógicas do cinema.

Preferimos entender que os códigos fílmicos pertencem, na verdade, à técnica do cinemá, usados para representar no filme a natureza das mensagens que lhe são típicas. Assim, por exemplo, no âmbito de um filme de terror, o enquadramento frontal do rosto dos personagens em pânico é usado como significante de uma mensagem de medo e, num filme de guerra, o enquadramento lateral panorâmico de uma batalha deve sempre aparecer na montagem finàl, pois é essencial para o significado da ação. São famosos os planos de enquadramento da face do rosto da atriz no filme Desencanto (1945), dirigido por David Lean, representando a forte tensão que resulta dos mergulhos mentais da personagem Laura em seu passado. Da mesma forma, são espetaculares em A Paixão de Joana D'arc (1928), filme dirigido por Carl Theodore Dreyer, os enquadramentos mostrando que as convicções morais da personagem eram superiores à forte tortura pela qual passava.

A semiologia prefere tratar o problema da caracterização terminológica necessária para estabelecer o lugar dos códigos na linguagem cinematográfica em termos de fatos gerais e fatos particulares. Assim, conviremos denominar de códigos cinematográficos gerais as instâncias sistemáticas (a serem construidas pela análise) a que serão atribuidos os traços que não apenas caracterizam propriamente a grande tela, mas, além disso, são comuns (efetiva ou virtualmente) a todos os filmes (p. 73, grifo do autor). Por sua vez, os códigos cinematográficos particulares agrupam traços de significação que aparecem 
somente em certas classes de filmes (e, nisso, são particulares), mas que, contudo, só se manifestam em filmes (no que são cinematográficos; [...] (p. 73, grifo do autor).

Com essa sistematização semântica, finalmente, as discussões dentro da análise metziana sobre as translações sofridas no tempo e no espaço pela significação lingüística estão encerradas: a linguagem cinematográfica passa a ser o sistema de todos os códigos particulares e gerais do cinema, entendido como o conjunto de todos os filmes. No entanto, mesmo assim, Metz não tem como desconsiderar a noção de gênero cinematográfico, da mesma forma que a semiologia dita do texto escrito não pode desconsiderar a literatura: [...] na linha de Metz [...] o cinema não deixa nunca de estabelecer relações com a literatura. $\dot{E}$, pois, teoricamente ajustado postular o cinema como linguagem que, no filmico, se articula e falar em linguagem cinematográfica em termos homólogos àqueles em que se fala em linguagem literária (Reis, apud Cardoso, p. 1).

Para Metz, a presença de códigos particulares "é muito sensível nos filmes pertencentes a um 'gênero' fortemente firmado como o western clássico; este manifesta um código (ou um conjunto de códigos) distinto dos que caracterizam os filmes em geral [...]" (p. 73). Pode-se descrever no western o tipo lógico específico de movimento da câmera em relação à sequiência do assalto à diligência e a prisão do bandido. Metz não dá esta explicação, mas a seqüência começa com a tomada panorâmica da diligência percorrendo velozmente um "perigoso" desfiladeiro. A tomada fecha com enquadramento frontal do bandido montado a cavalo e parado em uma passagem estreita do desfiladeiro, fazendo mira com uma arma. Não pode faltar o enquadramento do rosto "maldoso" do bandoleiro, mas o plano final recua para a "perigosa" arma. Na seqüência, há duas opções de montagem: o plano lateral ou o frontal do tiro. No primeiro, o efeito talvez seja mais interessante, pois não há necessidade de cortar a seqüência imediatamente: o corte só é feito para o condutor da diligência recebendo o tiro e caindo; no outro plano, a tomada recua para a diligência entrar na cena no momento do tiro. $O$ condutor cai e, a partir disto, interessa a seqüência da perseguição aos cavalos pelo bandido com a câmera em movimento lateral, mantendo sempre em foco o plano da diligência. 
Uma solução de enquadramento interessante é a que mostra o bandido em perseguição entrando no plano do movimento da diligência, chegando aos cavalos, parando-os, pegando as sacolas com o dinheiro e se afastando. Em seguida, pode-se montar a seguinte seqüência: flashback para um plano determinado pelo condutor caído no chão. O xerife entra no plano com o seu assistente, que salta para acudir o condutor. O enquadramento continua com a câmera em movimento, mantendo o xerife num plano fixo até passar pela diligência parada. Abre-se um plano panorâmico do xerife em perseguição ao bandido, que se fecha na medida em que ocorre a aproximação, até o enquadramento lateral do salto do xerife sobre o bandido, derrubando-o de seu cavalo. Toma-se a luta com a câmera parada e o xerife desarma o bandido, prendendo-o. Na seqüência, pode haver um flashforward com a câmera em movimento enquadrando a condução do bandido pelo xerife na entrada da cidade. $\mathrm{E}$, depois, há o enquadramento frontal do rosto do bandido atrás das grades etc.

Essa seqüência típica do western constitui um conjunto possível de soluções espaciais e temporais no qual há um código cinematográfico que é geral (pois se refere virtualmente a todos os filmes), mas que, ao mesmo tempo, é particular, visto que só mobiliza certas figuras significantes da tela (p. 77). Na seqüência do western descrita, os planos da ação, que variam do frontal ao panorâmico, desenvolvem-se dentro de dois tipos fundamentais de enquadramento: com a câmera parada e com a câmera em movimento. Os movimentos da câmera no cinema [...] têm como objeto específico um sistema que é geral sobre o eixo dos filmes [...] (p. 78).

O conjunto dos códigos cinematográficos gerais define um vocabulário significante que, além dos planos de enquadramento, contém ainda a montagem, o ângulo de tomada, a distorção, o flashback, o flashforword, o primeiro plano, o background etc. Este vocabulário permite falar dos aspectos imagéticos da linguagem cinematográfica, que são singulares dentro de cada contexto filmico e estão obviamente associados a outros elementos singulares também significantes, como, por exemplo, a trilha sonora. 
Dessa forma, as singularidades de cada filme apresentamse como um "texto" contendo entre outras coisas, diversos movimentos da câmera: cada um deles é uma mensagem (uma das numerosas mensagens) do códigö dos movimentos da câmera, isto é, de um código cinematográfico geral [...] (p. 89). A codificação das mensagens estabelecida pelo movimento da câmera - no caso do clássico filme $A$ regra do jogo (1939), de Jean Renoir - ocorre em termos das "entradas e saídas de campo", conceito voltado para a forma como os personagens penetram no espaço filmado e como o deixam. Há aí todo um sistema que faz parte da dramaturgia do cinema e não há dúvida de que, examinando desse ponto de vista o filme de Jean Renoir, compreetideremos melhor a natureza e o alcance exato desse código (p. 110). A codificação do campo modificou-se totalmente quando se pàssou da tela standard para a grande tela do cinemascope, ná déćada de 1950 .

Ao lado do movimento da câmera, os códigós que descrevem as formas de montagem fazem parte do vocabulário básico da linguagem cinematográfica è estão presentes na estrutura de significação de gêneros singulares de filmes, como os realizados pelos cineastas soviéticos no período 1925-1930, que definiram a "gramática da montagem". O filme de David Wark Griffith, Intolerância (1916), outro clássico, codificou a "montagem paralela" e a "aceleração", apresentando quatro episódios (mensagens) diferentes, montados de forma entremeada: inicialmente, as seqüências de cada episódio são mais longas; depois, diminuem em um ritmo cada vez mais rápido, até chegar a uma fusão completa.

Esta configuração, que domina todo o filme (e, literalmente, o une), não está evidentemente isenta de especificidades cinematográficas: como um meio de expressão (a lingua escrita, por exemplo), a alternância - e sua aceleração - não poderia ter se organizado numa roleta afetiva e visual tão direta, tão cerrada [...] (p. 128).

A montagem paralela define-se como um arranjo sintagmático que se opõe a outros encadeamentos icônicos possíveis, como a montagem alternada, na qual o retorno cíclico das imagens representa 
a simultaneidade dos acontecimentos no nível de uma cronologia literária. Outra forma de montagem, a alternância dos planos, corresponde à não-simultaneidade dos acontecimentos representados nos filmes. O código da montagem utilizado por Griffith resulta num texto filmico que permite "ler" os atos de fanatismo decorrentes do sentimento de intolerância pertencente à natureza humana como permanentes e presentes em toda parte. Griffith era amante das "mensagens humanas" e trouxe uma grande contribuição para a própria invenção da linguagem cinematográfica como um conjunto específico de códigos e subcódigos [...] (p. 133). Desta forma; o sistema fílmico presente em Intolerância corresponde à adoção de um determinado emprego da montagem paralela para apresentar uma forma específica de mensagem sobre o fanatismo humano.

Os textos literários e fílmicos retroagem sobre os códigos que os inspiraram e os fazem. voltar diferentes do sistema de onde foram extraídos. Este movimento evolutivo da linguagem do cinema é perceptível na leitura das unidades do conjunto das mensagens de um mesmo código que constituem os grupos de filmes. Metz entende os grupos de filmes como [...] um vasto texto coletivo que liga várias fronteiras interfilmicas (p. 153) em uma única unidade de expressão, determinando os gêneros cinematográficos: comédia, musical, film noir, western, nouvelle vague, policial etc. Cada um destes gêneros é constituído por uma classe de filmes que possuem códigos comuns. Tal atividade clasșificatória é realizada de duas formas possíveis: pode-se ordenar numa mesma classe todos aqueles [filmes] que apresentam um determinado emprego do movimento da câmera [...]; mas pode-se também considerar que todos os filmes de Murnau formam um único filme [classe] (p. 154).

Para Metz, no atual estágio da pesquisa, o segundo tipo de agrupamento é tido como mais "natural" do que o primeiro, pois permite determinar com mais precisão as unidades concretas do discurso semiológico. Os códigos particulares que formam as classes são subcódigos da totalidade dos filmes e a linguagem cinematográfica é [...] um amplo objeto único (p. 156). O problema lógico dessas 
"classes naturais" de Metz é que todos os filmes de um mesmo diretor não contêm necessariamente os mesmos subcódigos. É sabido; por exemplo, que, entre as produções de $O$ Encouraçado Potemkin (1925) e Alexander Nevsky (1938), a busca de Eisenstein por uma nova linguagem cinematográfica foi radical:

Nos anos 20, Eisenstein percebeu que as atrações individuais nunca poderiam ser responsáveis pelo significado do cinema e então introduziu o conceito unificador e dinâmico de montagem. No final daquela década e durante toda a década de 30 , ele empenhou-se em ultrapassar a montagem simples para chegar ao nivel da forma cinematográfica, pois se tornara claro que, apesar da energia vivificadora da justaposição de planos, a mera justaposição por si mesma nunca determinaria o impacto de um filme. A montagem é responsável pelo significado no nível local, mas não pelo significado total. (Andrew, 1989, p. 66)

Dessa forma, resta a classificação de acordo com a possibilidade aberta pelo emprego diferenciado dos movimentos da câmera. Pode-se até mesmo construir uma síntese generalizante e afirmar que os diretores utilizam a câmera de maneira que as variedades de movimentos que eles produzem determinam sempre classes naturais de subcódigos. Assim, por exemplo, no caso de Wim Wenders, o estilo 'travelling', seja no sentido específico de uma técnica de conduzir a câmera, ou no sentido genérico de viajar, é certamente sua maior característica (Ferreira Netto, 2001, p. 94). Seus clássicos road-movies são produzidos segundo movimentos lentos e cenas demoradas, mantendo-se fiel à luz natural e optando pelo realismo que tenta não modificar a natureza.

Em Paris-Texas (1984), Wenders utiliza planos de enquadramento abertos e muitos gerais, fragilizando os personagens e, ao mesmo tempo, integrando-os em imensas paisagens, conferindo uma dimensão épica à sua viagem solitária e errante. Juntamente com Werner Herzog e Rainer Werner Fassbinder, Wim Wenders fez 
surgir nas décádas de 1960 e 1970 o Novo Ćnemà Alemão. $O$ chamado cinema de vanguarda (Cinema Nov́o Alemão, Neorealismo italiano e Nouvelle Vague frâncêsis traz uma marca bem européia na concepção è na realizáção de um filmè que é uma maneira mais introspectivä, sensivel, pessoal, psicológica, filosófica e artística (Ferreira Netto, 2001, p. 87). Nesta perspectiva, o problema da definição das classes filmicas levanta a questão do papel dos gêneros cinematográficos dentro da semiologia.

Metż esclarece que os traçós de generalidade não entram em seu sistema semiológico " $O$ analista que deseja estabelecer o sistema de ù filme, precisamente designado, parte evidentemente déste filme (mesmo se o compara a muitos outros); mas não se segue, por algum estranho corolärio, que aquele que deseja estabelecèr um código cinematográfico parta de um filme mais gèral [...] (Metz, 1980, p.180). Assim, os gêneros cinematográficos - ou mesmo o conjunto de filmes de um único cineasta-pouco contribuem para com a organização de classes de subcódigos, pois quando se trata do conjunto de filmes de um cineasta como um amplo texto único, o 'filme' assim obtido não deixa de ser um certo filme (p. 180, grifô do autor).

Mesmo ùm gênero fortemente codificado, como o western, apresentou diversas modificações à longo do tempo. Em um dos primeiros grandes filmes do gênerò, No tempo das deligências (1939), de John Ford, à personalidade dos personagens retrata a natứreza trágica do oeste nórte-americano. Na diligência solitária, viajam pela paisagem desértica um médico alcoólatra, um pistoleiro, uma prostituta, um banqueiro, um jogador e uma mulher grávida. As dificuldades da longa travessia levarão cada um deles a revelar seu verdadeiro caráter. Os personagens que representam pessoas consideradas como respeitáveis rèvelam-se desrespeitosas e a prostituta age de forma muito mais ética do que supõem os preconceitos. $\mathrm{O}$ desnudamento do caráter é a coluna vertebral do filme, revelando a natureza trágica da civilização, obra incontornável das imperfeições humanas. Já em Paixão dos fortes (1946), John Ford integra o tom de paródia ao gênero western, o que é consagrado na década de 1950 em remakes como Sem lei, sem alma (1957), de 
John Sturges, ampliando os paroxismos do discurso da comédia satírica que ridiculariza a dramaticidade dos primeiros filmes. Com os faroestes italianos, principalmente em Era uma vez no Oeste (1969), de Sergio Leone, ocorre um processo de desconstrução do gênero, passando da paródia à crítica, mas apresentando ainda todos os subcódigos do western tradicional. [...] e o futuro nos reserva, sem dúvida, um certo número de excessos/prolongamentos suplementares. Assim ocorre com o texto infinito do que se denomina um gênero... (Metz, 1980, p.182, grifo e reticências finais do autor).

Os sistemas que constituem os gêneros filmicos estabelecem em termos semiológicos relações sintagmáticas e paradigmáticas, mas não classes de códigos. As relações paradigmáticas referem-se ao fato de que a produção global de cada cineasta freqüentemente alterna filmes de tipos diferentes, quando os gêneros são confrontados de forma a se tornarem textos plurifilmicos, como o policial clássico e o "filme negro" das décadas de quarenta e cinqüenta. $[\ldots] \mathrm{em}$ todos os casos desse tipo, é um sistema textual inteiro que se torna elemento parcial de um conjunto mais amplo e esse conjunto é um paradigma (p. 208). Os gêneros filmicos podem também ser entendidos no sentido semiológico como sintagmas, sistemas textuais plurifilmicos que resultam de códigos semiológicos diferentes, compreendendo todos os traços de todos as classes de subcódigos, "quer seja por semelhança direta, por homologia, por inversão, por defasagem, por jogo de espelho, 'contraste' etc" (p. 208).

Essa colocação em sintagma é sempre acompanhada de uma colocação em paradigma. Em oposição à tentativa de classificação dos códigos em termos de gêneros filmicos, "desde que algumas pesquisas cinematográficas adotaram uma perspectiva mais ou menos semiológica, isto é, há alguns anos apenas, certos autores colocaram o problema da unidade mínima no cinema e, às vezes, começaram a propor formas de solução" (p. 219, grifo do autor). Um exemplo de unidade mínima considerada por muitos autores é o fotograma, proposto como o menor segmento cinematográfico. No trabalho de Umberto Eco sobre a triplice articulação do cinema, [...] o fotograma desempenha um papel importante. Recentemente, 
autores como Roland Barthes e Sylvie Pierre examinaram a noção de fotograma [...] (p. 226). Mas as unidades pertinentes ao fotograma correspondem na verdade a diferentes subcódigos que se distinguem sobre o eixo do filme, como as filmagens em continuidade do cinema moderno. Desta forma, a unidade mínima, variando consideravelmente em relação aos subcódigos presentes em determinado filme, não podem servir como critérios de classificação na semiologia cinematográfica.

As unidades mínimas são os "achados" mais avançados da semiologia do cinema, que continua a apresentar dificuldades por não ter conseguido até agora classificar os códigos presentes nos sistemas filmicos e seus avanços são pouco significativos. No entanto, Metz pensa que o grupo de códigos incorporados ao funcionamento tecnológico da câmera cinematográfica constitui de fato uma unidade mínima do qual o fotograma é o elemento concreto resultante. [...] pensamos nos códigos tecnológicos que são incorporados ao próprio funcionamento do aparelho cinematográfico (da câmera), que são o fotograma (no sentido em que se fala da programação de um computador), que constituem o próprio principio de sua fabricação, de seu funcionamento, de suas regulagens (p. 227, grifo do autor). Tais códigos são relacionados à câmera enquanto uma máquina destinada a captar o movimento dos objetos e registrá-lo imprimindo informações que deverão ser, depois da montagem, decodificadas pelos espectadores quando assistirem à projeção do filme.

O princípio do cinema é dessa forma o complexo sistema dos códigos possíveis de ser materializados pelo instrumental cinematográfico representado pela câmera registradora. Os códigos de montagem constituem outra unidade mínima fundamental e estes permitem fazer a análise dos fotogramas anteriormente obtidos para a elaboração dos efeitos complementares de um filme. $\mathrm{Na}$ grande época do cinema soviético, o plano era um conceito de primeira importância para as teorias e as práticas de montagem. Cada plano, em princípio, era construído com a câmera em torno de um motivo único e central que isolava a composição visual do filme. Fazia-se uma montagem plano a plano do material filmado, ao contrário do 
cinema moderno, em que alguns filmes desenrolam-se por meio de cenas constituídas de um plano único e bem longọ, denominado planoseqüência. Os códigos da câmera e da montagem sofrem mudanças conforme as novas tecnologias implementam; formas diferenciadas de trabalho cinematográfico, gerando subcódigos que aparecem historicamente'em contextos como a escola soviética dos anos vinte, as diversas modalidades de cinema novo, as filmagens em continuidade do cinema moderno, os efeitos especiais etc.

O ceticismo a propósito das possibilidades da semiologia do cinema passa a ser minimizado quando se considera o movimento de câmera como ùm signo. Mesmo se o significado dos movimentos da câmera variar consideravelmente de um sistema filmico para outro, eles têm sempre um sentido definido. Para Metz, o movimento da câmera, é o meńor elemento que tem um sentido (um travelling tem um sentidö, uma metade de travelling não tem, [...]: apenas se pode comutar globalmente um 'travellin-para a frente' e um 'travelling-para trás', ou ain'da travelling e sua 'ausênciá, isto é, um travelling e um plano fixö)" (p. 245): Com isso, a discussão sobre os recursos propiciados â linguagem cinemátográfica pelas tecnologias emergentes constitui o objeto atual do legado semiológico de Christian Metz.

\section{Consịderações finais: os códigos digitais do cinema}

Novas gerações de equipamentos cinematográficos são desenvolvidas continuamente e permitem a produção de filmes com recursos de linguagem ainda inexplorados. $O$ aperfeiçoamento da câmera digital de cinema é a grande promessa tecnológica da presente década e o computador já é utilizado desde antes da década de 1990 para a obtenção dos revolucionários efeitos especiais $O$ çomputador abre espaço para a mistura de figuras captadas das mais variadas formas (registros em movimento, fixos, desenhos.), passando a criar um novo: nivel de representação (Mourão, $\mathrm{p}$. 124). Nas novas práticas do cinema, o neo-realismo italiano se 
consolida completamente diante da sua preocupação com o registro do tempo integral, os chamados 'tempos mortos', de interregno entre uma ação e outra, até então eliminados da montagem do modelo Griffith (p. 119).

Com a câmera digital, pode-se ter em um mesmo equipamento a câmera comum e a mesa de montagem, sendo ambas operadas simultaneamente. Trata-se da fusão do laptop com a câmera de mão nos modelos portáteis e do personal computer com a câmera de ancoragem no set de filmagem. Este fato significa integrar ao sistema da câmera a mesa de edição, pois com os liquid cristal displays há retorno imediato do material filmado e o cineasta pode realizar montagens no próprio local de registro de imagens e sons, permitindo que resultados próximos da edição final sejam analisados em consonância com os trabalhos iniciais de enquadramento, obtenção da profundidade de campo, angulação, movimentos da câmera etc.

A realidade filmica encontrada no campo visual abarcado pela objetiva da câmera funde-se com imagens previamente programadas para compor fotogramas em que o real é enquadrado pelo cinegrafista sobre o campo virtual formado por imagens já registradas. A noção de plano sofrerá importantes aprofundamentos com o cinema digital: no long-shot, determinado pela grande distância entre a câmera e o objeto filmado, a duração focal modificará também os fotogramas virtuais com os quais a realidade filmica se funde, aproximando-os, afastando-os ou podendo angulálos; no medium-shot, os enquadramentos voltados para a visualização dos movimentos dos personagens que interagem entre si e com o ambiente vão experimentar possibilidades visuais nunca exploradas, pois os recursos de fusão de atores com cenários virtuais podem produzir efeitos estéticos dramáticos e cômicos inovadores; no two-shot, o problema da construção de cenários não obstrutivos para o claro delineamento dos gestos corporais dos personagens encontrará soluções novas com efeitos inesperados; no close-up, os elementos de significação psicológica, que despertam a comicidade ou a dramaticidade, dados pela expressão facial dos personagens serão facilitados pela disposição de liquid cristal 
displays em qưe o ator, podèndo se ver como em um espelho, terá a chance de levar sua atuação para resultados que de outra forma seriam màis dificeis de obter; no big close-up, os detalhes enfocados póderão sér imediatämente testados em termos' de sua edição e projeção; permitindo ao diretor estudar os mélhöres efeitos' de filmágem de uma cena.

Com o c̀nema digital as müdançás de tomada de planos efetuadas pelos cuts - cortes - poderão ser realiżadas em tempós mortos totalmente sem interrupção, ou seja, as hovas fórmas de travelling permitirão que a busca da expressão da realidade revele horizontes inexploradós da linguagem cinematográfica: Assim, o ciñemă digital promete ap̣roximär a lingúágem sistematižadòra de Griffith à estrutura narrativa consagrada pelo neo-realismo de Godart.

Penso que, no curto espaço de tempo dos últimos dez anos, as novas tëcnologias começaram certamente a mudar as formas de arte já aceitas, e estou totalmente convencido de que todas as novas tecriologias visuais, as tecriologias pós-televisuais, vão söfrer um gránde desenvölvimento. $E$ ácredito que, com isto, haverá uma mudança do cónceito que temos da forma de arte do século" $X X$ chamada cinema. Estas" são minhas cônsideraçôes, "mas talvéz eu parta de um background diférente, uma vez que minha formação inicial é a de pintor, e o pintór tem umá hábilidade onipotente de reorganizar o mundo, especialmente depois das formas de linguagem desenvolvidas no século $X X$. Acho que a partir 1850, 'quando as noções de cor e forma divorciaram-se do conteúdo, houve uma explosão enorme ña atividade da manipulação' visual. As novas invençôes tecnológicas, as tecnologias pós-televisuais, permitiramme voltàr a ser um "pintor. Não só com a liberdade, "póderíamos dizer, de Leónardo da Vinci ou David, mas a liberdade de uim Picassso ou um pós-Picasso: Assim, agora, qualquer coisa é possivel: Eu estou completamente encantádo com isto. (Grenaway, 2004, p. 181) 
Os processos cinematográficos introduzidos por Orson Welles com a fusão e síntese de várias ações pela sobreposição de planos formados por cenas dispostas simultaneamente na profundidade do campo captado pela câmera - codificação que caracterizou também o neo-realismo italiano - conduziram a uma profunda mudança na forma de produzir cinema e na forma como o telespectador assiste a um filme. A condução narrativa não linear do filme permitiu que o telespectador passasse a ter muito mais o que olhar em cada plano mostrado. Com as possibilidades abertas pelas tecnologias digitais, o cinema já conta neste início de século com programas de computador capazes de fundir com precisão cenas que se passam diferencialmente em planos temporais distintos, indo muito além da simples profundidade de campo. Trata-se da perspectiva de explorar ao máximo a manipulação das imagens, rompendo os limites entre passado e presente com a visualização de várias temporalidades no mesmo plano. Fazendo avançar os limites tradicionais da produção cinematográfica, as novas tecnologias apresentam produtos que se caracterizam pela mistura de elementos da linguagem televisiva, do cinema e da pintura. Esse processo ocorre dentro da pesquisa atual com os sistemas de hipermídia e $o$ estudo filosófico-prático sobre a linguagem do cinema interessa ao processo de roteirização da hipermídia, porque discute o potencial das interações entre os seus mais íntimos e mínimos elementos (Gosciola, 2003, p. 113). No caso da Internet, o sistema hipermediático está diretamente relacionado com a montagem paralela do cinema, graças à possibilidade de o usuário acessar vários conteúdos e mídias simultaneamente. Nos games, que constituem a produção hipermediática mais elaborada pelos meios propiciados pela Word Wide Web, o cinema forneceu os códigos da profundidade de campo, permitindo ao usuário uma visão mais detalhada de cada plano em jogo. A condução narrativa visual não linear, adotada pela linguagem do cinema moderno iniciado com Welles e Godart, possui um importante significado na produção dos games. Há um enorme conjunto de códigos de linguagem emprestados pelo cinema à hipermídia: o rigor do enquadramento para a composição da tela; o close-up como mecanismo de clicar para ampliar; o movimento da 
câmera como princípio de controlar rigorosamente as localizações dos objetos na cena em jogo; os inserts dos próprios filmes ou de vídeos na área de interação do usuário; o fade-out $\mathrm{e}$ o fade-in como efeitos de transição de um nível de dificuldade do jogo para outro; ò match-cut como signnificação do deslocamento temporal das batalhas; o jump-cut como corte brusco para a inserção de personagens, cujas regras para jogar foram alteradas etc. Os novos autores do cinema digital trabalhạm em equipe e incorporam simultaneamente os papéis do diretor, do roteirista, do produtor e do ator.

No âmbito da semiologia, a linguagem digital do cinema aponta para o problema de se determinar a classe dos signos formados a partir da fusão intercódiga da hipermídia. Trata-se de estudar quais signos podem deslocar a função social do cinema para o nível da decodificação política da linguagem escrita, visual e sonora, produzida pelos diversos meios de comunicação de massa, como em Fahrenheit 11 de setembro (2004) de Michael Moore, que utiliza simultaneamente imagens de televisão e cinema para montar um filme-documentário que produziu grande impacto sobre a reflexão a respeito do fenômeno geopolítico contemporâneo da globalização. A produção investiga os bastidores e os desdobramentos dos atentados terroristas ocorridos nos Estados Unidos, em 11 de setembro de 2001, mostrando os paralelos entre as duas gerações da família Bush que já comandaram o país e as relações entre o atual presidente americano, George W. Bush e Osama Bin Laden. O filme baseia-se no tema da guerra; que conforme explicou Walter Benjamin, produz uma satisfação artística na qual a destruição corresponde ao gozo estético, mas a mensagem é montada no sentido de mostrar a insanidade da Guerra do Iraque e amplia, desta forma, a percepção política do telespectador, e não, a sua alienação. 


\section{Bibliografiá}

A PAIXÃO DE JOANA D'ARC 1928. Direção de Carl Theodore Dreyer. França. Intérpretes; Falconetti; Antonin Artaud; Michel Simon. 1 DVD' (82 min), mudo, preto é branco. Distribùição: Continental Home Vídeo:"

A REGRA DO JOGGO 1939. Direção de Jean Renoir. França. Intérpretes: Nora Gregor, Rolland Toutain, Paulette Dúbostit; Odette Talasak. 1 DVD (110 min), son., preto e branco. Distribüição: Versátil Home Vídeo.

AIEEXANDER NEVSKY. 1938. Direção: Sergei Eisenstein. Rúśsiá. Intérpretes: Nicolai Cherkassov; N. P. Okhlopkov;'V. S. Ivashevá. 1 DVD (108 min), son., dolby digital, preto e branco. Distribuição: Continental Home Vídeo.

ANDREW, J. D. 1989. As principais teorias do cinema. . Rio de Janeiro: Jorge Zahar.

ARNHEIM, R. 1980. On Tourne. Apud BENJAMIN, W. A obra.de arte na época de suas técnicas de reprodução. São Paulo: Abril.

BARTHES, R. 1985. A aventura semiológica. Lisboa: Edições. 70. 1971. Eleméntos de semiologia: São Paulo: Cultrix/EDUSP. 1966. Critica e verdade. Lisboà: Edições 70.

BAZIN, A. 1991. O Cinema: ensaịos. São Paulo, Brasiliense.

BENJAMIN, W. 1980. A obra de arte na época de suas técnicas de reprodução. São Paulo: Abril.

CARDOSO, L. M. O. B. 2004. Literatura e cinema: simbioses narratológicas. Disponível em: <http://www.ipv.pt/forumedia/5/ 17.htm\#notas>. Acesso em 13 jun. 2004.

DESENCANTO (Brief Encounter). 1945. Direção de David Lean. Inglaterra. Intérpretes: Celia Johnson, Trevor Howard, Stanley Holloway, Joyce Carey, Cyril Raymond. 1 videocassete $(86 \mathrm{~min})$, VHS, mono, preto e branco. Distribuição: 2001 Vídeo.

ECO, U. 1984. Semiotics and the Philosophy of Language. Bloomington: Indiana University Press.

ERA UMA VEZ NO OESTE (Once Upon a Time in the West / C'era una volta il West). 1969. Direção de Sergio Leone. Itália / 
$\because$ Estados Unidos. Intérpretes: Claudia Cardinale, Henry. Fonda, Jàsón Robar̂̀ds; Charles Brońson.' l. DVD (140 min). Distribuição: CIC / Paramount.

FÄHRÉENHEIT 11 DE SETEMBRO (Fahìnheit:11/9): 2004. Direção: Michaèl Moore. Estados Unidos. Itérprete: Michael Moore. 1 bobina cinematográfica (116 min), son., color., $35 \mathrm{~mm}$. Distribuição: Lions Gate Films Inc. / IFC Films / Europa Filmes.

FERREIRA NETTO; G. A. 2001. Wim Wenders: psicanálise e cinema. São Paulo: Unimárco.

GIBSON, J A theory of pictorial perception. Apud SANTAELLA, Lucia \& NÖTH, Winfried. 1998. Imagem: cơgnição, sémiótica, mídia. Sãó Ṕaulo: Iluminuras.

GOSCIOLA, V. 2003. Roteiro para as novas midias: do game à TV interativa. São Paulo: Senac.

GREENAWAY, P. Entrevista concedida a MOURÃO, Maria D. Cinema e novas tecnologias: conversa com Peter Greenaway. In MACIEL, Maria E: (org.). 2004: O cinema enciclopédico de Peter Greenaway: São Paulo: Unimarco, p. 179-190:

INTOLERÂNCIA. 1916. Direção: David Wark Griffịth Estados Unidos. Intérpretes: Lilian Gish, Robert Harron. Bessie Love, Miriam Cooper, Mae,Marsh, Constance Talmadge 1 videocassete (19.7 min), VHS, múdo, preto e branco. Distribuição: 2001 Vídeo.

GOODMAN, N. Problems and projects. Apud SANTAELLA; Lucia \& NÖTH, Winfried. 1998. Imagem: cognição, semiótica, midia. São Paulo: Iluminuras.

MACIEL, M. E. (org.). 2004. O cinema enciclopédico de Peter Greenaway. São Paulo: Unimarco.

METZ, C. 1980. Linguagem e cinema. São Paulo: Perspectiva.

MOURÃO, M. D. Greenaway e as influências das novas tecnologias na linguagem cinematográfica. In MACIEL, Maria E. (org.). 2004. O cinema enciclopédico de Peter Greenaway. São Paulo: Unimarco. p. 117-26.

NO TEMPO DAS DELIGENCIAS (Stagecoach). 1939. Direção: John Ford. Estados Unidos. Intérpretes: Claire Trevor, John Wayne, Andy Devine, John Carradine. 1 DVD (97 min), son., preto e branco. Distribuição Continental Home Vídeo.

O ENCOURAÇADO POTEMKIN. 1925. Direção: Sergei Eisenstein. Rússia. Intérpretes: Alexander Antonov, Vladimir 
Barsky, Grigory Alexandrov, Marusov, Mikhail Gomorov. 1 DVD (74 min), son;, preto e branco. Distribuição: Continental Home Vídeo.

PAIXÃO DOS FORTES (My Darling Clementine). 1946: Direção: John Ford. Estados Unidos. Intérpretes: Henry Fonda, Linda Darnell, Victor Mature. 1 videocassete $(97 \mathrm{~min})$, VHS, son., preto e branco. Não distribuido no Brasil.

PARIS-TEXAS. 1984. Direção: Wim Wenders. Alemanha/França. Intérpretes: Harry Dean Stanton, Nastassja Kinski, Dean Stockwell, Aurore Clément, Hunter Carson, Bernhard Wicki. 1 DVD (145 min), son., cor. Distribuição: MercadoLivre Brasil.

PEIRCE, C. S. 1995. Semiótica. 2 ed. São Paulo: Perspectiva.

PIAGET, J. \& INHELDER, B. 1993. A representação do espaço na criança. Porto Alegre: Artes médicas.

REIS, C. 1997. Dicionário de Narratologia. Apud CARDOSO, Luís. M. O. B. Literatura e cinema: simbioses narratológicas. Disponível em: <http://www.ipv.pt/forumedia/5/17.htm\#notas $>$. Acesso ém 13 jun. 2004:

SANTAELLA, L. \& NÖTH, W. 1998. Imagem: cognição, semiótica, mídia. São Paulo: Iluminuras.

SEMLEI SEM ALMA (Gunfight at the O. K. Corral). 1957. Direção: John Sturges. Intérpretes: Burt Lancaster, Kirk Douglas, Rhonda Fleming. 1 DVD (122 min), son., cor. Distribuição: Paramount Home Entertainment.

WERFEL, F. Ein Sommernachtstraum. Apud BENJAMIN, W. 1980. A obra de arte na época de suas técnicas de reprodução. São Paulo: Abril. 